\title{
Anti-Proliferative Effects of Hesa-A on Human Cancer Cells with Different Metastatic Potential
}

\author{
Rana Jahanban-Esfahlan ${ }^{1,2}$, Mozhgan Abasi ${ }^{1}$, Hakimeh Moghaddas Sani ${ }^{1,3}$, \\ Mehran Mesgari Abbasi ${ }^{2,4}$, Abolfazl Akbarzadeh ${ }^{3,5 *}$
}

\begin{abstract}
Background: During the past few years, Hesa-A, a herbal-marine mixture, has been used to treat cancer as an alternative medicine in Iran. Based on a series of studies, it is speculated that Hesa-A possesses special cytotoxic effects on invasive tumors. To test this hypothesis, we investigated the selective anticancer effects of Hesa-A on several cancer cell lines with different metastatic potential. Materials and Methods: Hesa-A was prepared in normal saline as a stock solution of $10 \mathrm{mg} / \mathrm{ml}$ and further diluted to final concentrations of $100 \mu \mathrm{g} / \mathrm{ml}, 200 \mu \mathrm{g} /$ $\mathrm{ml}, 300 \mu \mathrm{g} / \mathrm{ml}$ and $400 \mu \mathrm{g} / \mathrm{ml}$. MTT-based cytotoxicity assays were performed with A549 (lung non small cancer), MCF-7 (breast adenocarcinoma), SKOV3 (ovarian cancer), and PC-3 (prostate adenocarcinoma) cells. Results: All treated cancer cells showed significant $(P<0.01)$ or very significant $(P<0.0001)$ differences in comparison to negative control at almost all of the tested doses $(100-400 \mu \mathrm{g} / \mathrm{ml})$. At the lower dose $(100 \mu \mathrm{g} / \mathrm{ml})$, Hesa-A reduced cell viability to $66 \%, 45.3 \%, 35.5 \%, 33.2 \%$ in SKOV3, A549, PC-3 and MCF-7 cells, respectively. Moreover, at the highest dose $(400 \mu \mathrm{g} / \mathrm{ml})$, Hesa-A resulted in $88.5 \%, 86.6 \%, 84.9 \%$ and $79.3 \%$ growth inhibition in A549, MCF-7, PC-3 and SKOV3 cells, respectively. Conclusions: Hesa-A exert potent cytotoxic effects on different human cancer cells, especially those with a high metastatic potential.
\end{abstract}

Keywords: Hesa-A - metastatic cancer cells - anti tumoral effects

Asian Pac J Cancer Prev, 16 (16), 6963-6966

\section{Introduction}

In unaltered form, natural chemotherapeutic agents are acknowledged as effective remedies to combat different types of human disease including cancer with less concern about the possible side effects on healthy cells (Nasiri et al., 2013; Valiyari et al., 2013; Abbasi et al., 2014b). Hesa-A is an Iranian new immunomodulating medication with natural biological compounds, which has been patented by Ahmadi et al, 2002 in Iran for its biological properties. Hesa-A is a mixture of herbalmarine substances and includes Penaeus latisculatus (king prawn), Apiumgraveolens and Carumcarvi. It is composed of $50 \%$ inorganic substance, $45 \%$ organic substance (aminoenthraquinone) and 5\% water. The inorganic component consists of calcium carbonate, potassium, magnesium phosphate and sulfate and sodium and elements such as zinc, aluminum, potassium, cobalt, chrome, bromine, iron, and strontium at high concentrations (Ahmadi et al., 2010a).

Ahmadi et al in 2005, tested the effects of $50 \mathrm{mg} / \mathrm{kg} /$ day of Hesa-A on twenty four end staged breast cancer patients with retina choroid metastases. Their findings indicated that $92 \%$ of the patients who received Hesa-A at a dosage of $50 \mathrm{mg} / \mathrm{kg} /$ day orally lived with notably improving quality of life through the six months of the study. These patients suffered fewer complications and survived longer (Ahmadi et al., 2005).

In the second study by Ahmadi et al in 2009, authors investigated therapeutic effects of Hesa-A in fifty consecutive patients with end-stage colon cancer and liver metastasis. Patients received Hesa-A $50 \mathrm{mg} / \mathrm{kg} / \mathrm{d}$ orally in 2 to 3 divided doses for 6 months. The authors concluded that Hesa-is an effective and safe anticancer drug, in treatment of selected patients with less side effects (Ahmadi et al., 2009).

In another clinical trial study by Ahmadi et al in 2010, thirty consecutive patients ( 18 men, 12 women) with endstage cancers and liver metastasis were studied. Patients received Hesa-A $50 \mathrm{mg} / \mathrm{kg} / \mathrm{d}$ orally in 2 to 3 divided doses for 3 months. Result showed that a total of $90.4 \%$ of the patients who remained in the study were alive for 12 weeks. No significant hepatic or hematologic adverse effect was seen during the study (Ahmadi et al., 2010b).

In 2013, Mehdipour et al evaluated the effect of two systemic doses of Hesa-A on prevention of induced tongue 
neoplasm in rats. Their results indicated that Hesa-A has dose-dependent inhibitory effects on the development of neoplasms of the tongue (Mehdipour et al., 2013)

At the other hand, our unpublished data indicate that oral doses of Hesa-A improve clinical outcome of tongue carcinoma in rat. Tongue carcinoma is the most malignant neoplasm of oral cavity that mostly represents an unfavorable fatal prognosis(Abbasi et al., 2014a; 2014c).

It is speculated that aggressive tumors with high propensity for invasion may benefit more from cytotoxic effect of Hesa-A, in order to test this hypothesis we evaluated the effects of Hesa- A on a series of human cancer cells with a different metastatic potential.

\section{Materials and Methods}

\section{Hesa-A preparation}

A portion of Hesa- A as a fine powder was dissolved in acidic saline ( $\mathrm{pH}$ was adjusted to 1.5 , using $\mathrm{HCl}$ ) and shaked for $30 \mathrm{~min}$. The mixture was then filtered and its $\mathrm{pH}$ adjusted to $7.4 \mathrm{using} \mathrm{NaOH}$. Using $0.22 \mathrm{~m}$ microbiological filters, this solution was sterilized and kept frozen as a stock solution prior to its use (concentration of Hesa -A in this solution was $10 \mathrm{mg} / \mathrm{ml}$ ). From stock solution the final concentrations of 100, 200,300 and 400 $\mu \mathrm{g} / \mathrm{ml}$ were prepared and used in the cytotoxicity assay.

\section{Cell Culture}

MCF-7(human breast adenocarcinoma), SKOV3 (human ovarian carcinoma), A549 (lung non small cancer) and PC-3 (human prostate adenocarcinoma ) cells were obtained from the Pasture Institute (Tehran-Iran ). Cells were grown in RPMI 1640 supplemented with $10 \%$ heatinactivated fetal bovine serum (FBS), penicillin (10 U/ml), streptomycin $(10 \mu \mathrm{g} / \mathrm{ml})$ and $0.2 \mathrm{mM}$ sodium pyruvate. Cultures were incubated in the presence of $5 \% \mathrm{CO}_{2}$ at $37^{\circ} \mathrm{C}$ and $100 \%$ relative humidified atmosphere.

Determination of Cell Survival by the MTT Reduction Assay

Cancer cells were seeded in 96-well microplates at a density of $10 \times 10^{3}$ cells/well and grown for $24 \mathrm{~h}$ at $37^{\circ} \mathrm{C}$ in $5 \% \mathrm{CO}_{2}$ prior to the addition of test samples. Cells were treated with various concentrations of samples (100$400 \mu \mathrm{g} / \mathrm{ml}$ ) dissolved in Dulbecco's phosphate buffered saline (PBS). After $72 \mathrm{~h}$ of incubation, cell viability was determined using the colorimetric MTT assay. MTT solution at $5 \mathrm{mg} / \mathrm{ml}$ was dissolved in $1 \mathrm{ml}$ of PBS and $200 \mu \mathrm{l}$ of it was added to each of the 96 wells and were incubated at $37^{\circ} \mathrm{C}$ for 2 hours. Afterwards, the solution in each well were removed and were replaced with 100 $\mu \mathrm{l}$ of DMSO in each well. Then cell survival (\%) was measured as reduction of MTT into formazan at $550 \mathrm{~nm}$. Toxol with a final concentration of $20 \mu \mathrm{g} / \mathrm{ml}$ was used as positive control. Untreated cells (at $0 \mu \mathrm{g} / \mathrm{ml}$ ) were chosen as the negative control. Controls and samples were assayed in triplicate for each concentration and replicated three times. The percentage of cytotoxicity and cell viability were calculated using following equation:

$\%$ Growth Inhibition $=(1-O D$ extract treated $) / O D$ negative controlx100.

$\%$ Cell viability= 100- \% Growth inhibition

\section{Statistical analysis}

All the data represented in this study are mean \pm SEM of three identical experiments made in three replicate. Statistical significance was determined by analysis of variance, followed by LSD test and p-value $\leq 0.01$ was considered significant. All analyses were conducted using the SPSS 16.

\section{Results}

The cell proliferation inhibition was registered at 4 different doses and after a $72 \mathrm{~h}$ exposure (Table 1, Figure 1 and Figure 2).

SKOV3 cell line: Except dose $100 \mu \mathrm{g} / \mathrm{ml}$, all tested doses showed significant differences compared to negative control. IC50 for this cancer cells obtained at $200 \mu \mathrm{g} / \mathrm{ml}$ doses in which Hesa-A caused to $51.28 \%$ growth inhibition of ovarian cancer cells. At the highest concentration, Hesa-A caused to maximum growth inhibition of $79.3 \%$. In this cell lines, $20 \mu \mathrm{g} / \mathrm{ml}$ Toxol ( positive control) caused to $93.76 \%$ growth inhibition of SKOV3 cancer cells.

MCF-7 cancer cells: Significant $(\mathrm{P}<0.01)$ or very significant $(\mathrm{P}<0.0001)$ differences were found in comparison to negative control at all tested doses (100-400

Table1.\% Growth inhibition of Hesa-A extract on different human cancer cells

\begin{tabular}{lrccr}
\hline \multicolumn{5}{c}{ \% Growth Inhibition (72 h) } \\
\hline $\begin{array}{l}\text { Doses } \\
(\mu \mathrm{g} / \mathrm{ml})\end{array}$ & SKOV3 & MCF-7 & PC-3 & A549 cells \\
\hline 400 & $79.3 \pm 5.2$ & $86.57 \pm 7.2$ & $84.85 \pm 7.7$ & $88.45 \pm 7.1$ \\
300 & $67.85 \pm 3.0$ & $77.85 \pm 3.6$ & $75.57 \pm 3.8$ & $75.0 \pm 3.3$ \\
200 & $51.28 \pm 4.4$ & $71.28 \pm 2.4$ & $70.25 \pm 8.1$ & $64.28 \pm 4.9$ \\
100 & $34.0 \pm 6.1$ & $66.85 \pm 8.3$ & $64.47 \pm 5.5$ & $54.71 \pm 4.5$ \\
\hline
\end{tabular}
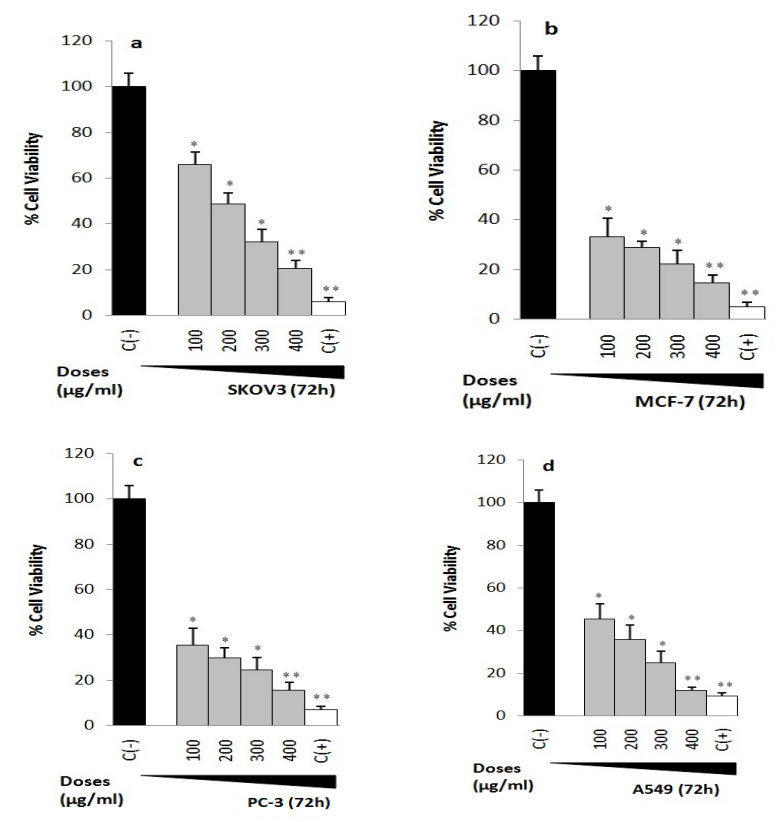

Figure 1. Hesa-A Inhibit Different Human Cancer Cell Proliferation in vitro. ${ }^{*} \mathrm{p}<0.01 ; * * \mathrm{p}<0.001$, compared to the negative control 
(a)

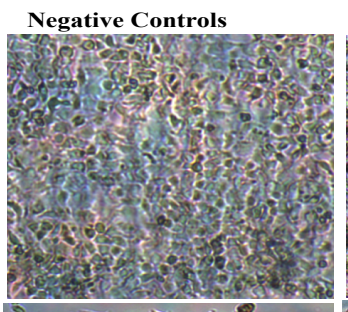

(b)

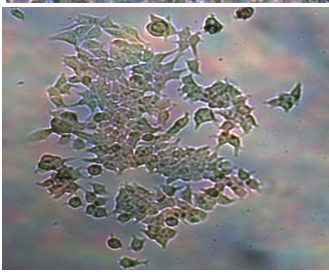

(c)

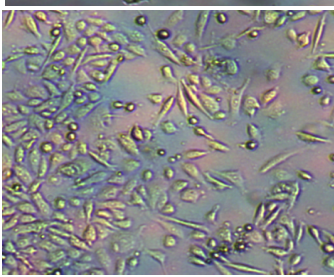

(d)
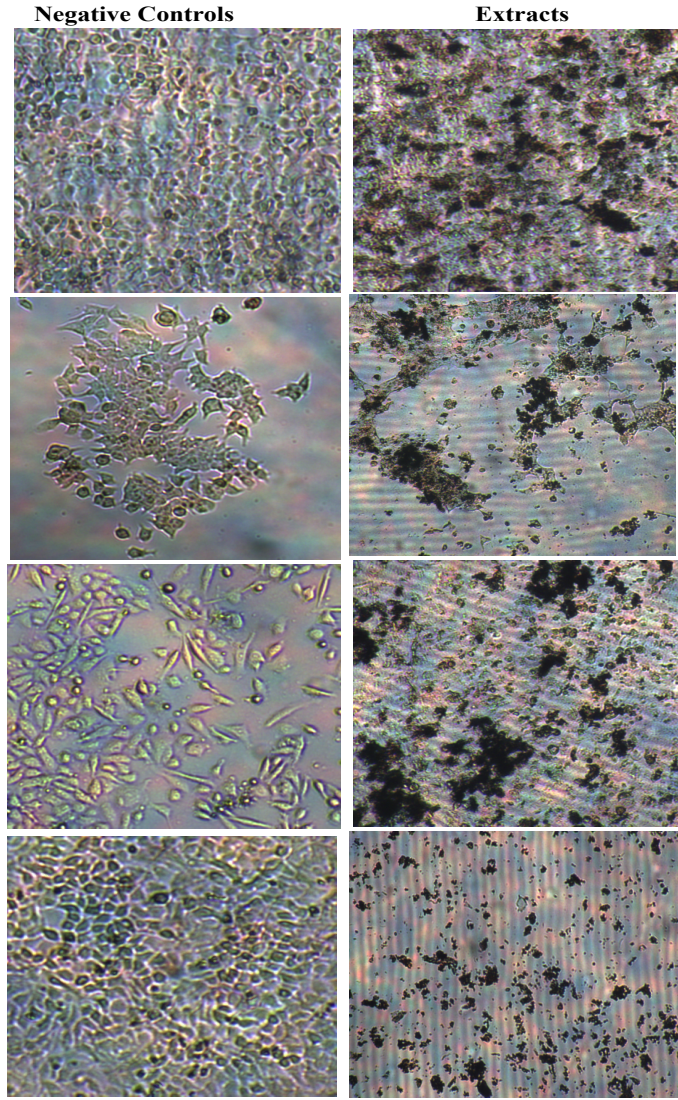

Figure 2. Cytotoxic Effect of Hesa-A on human SKOV3 (a), MCF-7 (b), PC-3(c) and A549 (d) cell lines after 72h exposure

$\mu \mathrm{g} / \mathrm{ml}$ ), reaching values to $33.15 \%$, even the lowest dose $(100 \mu \mathrm{g} / \mathrm{ml})$ after $72 \mathrm{~h}$ of treatments. Hesa-A caused to $50 \%$ growth inhibition obtained at doses $<100 \mu \mathrm{g} / \mathrm{ml}(66.85 \%)$ and the highest dose $(400 \mu \mathrm{g} / \mathrm{ml})$ caused to $86.57 \%$ growth inhibition of breast cancer cells, value comparable to that of $20 \mu \mathrm{g} / \mathrm{ml}$ Toxol which caused to $95.1 \%$ growth inhibition of MCF-7 breast adenocarcinoma cells.

PC-3 cancer cells: Hesa-A caused the lowest cell viability of $15.15 \%$ at a concentration of $400 \mu \mathrm{g} / \mathrm{ml}$ after $72 \mathrm{~h}$ of treatment. Toxol reduced the cell viability to $6.8 \%$ in PC-3 cancer cells (fig 1). All tested doses showed significant differences compared to negative controls. Even the lowest dose $(100 \mu \mathrm{g} / \mathrm{ml})$ caused to $>50 \%$ growth inhibition $(66.47 \%)$ in this cell line (Table 1). Figure 2 shows the potent cytotoxic properties of Hesa-A on PC-3 cells $(400 \mu \mathrm{g} / \mathrm{ml})$ after a $72 \mathrm{~h}$ exposure.

A549 cell line: All tested doses showed significant differences compared to negative controls. At the highest doses, cell viability reduced to $11.55 \%$, value close to $20 \mu \mathrm{g} / \mathrm{ml}$ Toxol which caused to $10.25 \%$ cell survival of A549 cells. IC50 for this cancer cells obtained at $100 \mu \mathrm{g} / \mathrm{ml}$ doses in which Hesa-A caused to $54.71 \%$ growth inhibition of lung cancer cells. At the highest concentration, it caused to maximum growth inhibition close to $88.45 \%$ (Table 1). Figure 2 shows the potent cytotoxic properties of Hesa-A on A549 cells $(400 \mu \mathrm{g} / \mathrm{ml})$ after a $72 \mathrm{~h}$ exposure.

\section{Discussion}

Cancer still continuous to be world wide killer
(Jahanban Esfahlan et al., 2011). Global cancer burden rises to 14.1 million new cases in 2012 and marked increase in breast cancers must be addressed. Furthermore, according to the 2014 cancer statistics in United Sates, Among men, cancers of the prostate, lung and bronchus, and colorectum will account for about $50 \%$ of all newly diagnosed cancers ,as prostate cancer alone will account for $27 \%(233,000)$ of incident cases in men. The 3 most commonly diagnosed types of cancer among women in 2014 will be breast, lung and bronchus, and colorectum, accounting for one-half of all cases in women. Breast cancer alone is expected to account for $29 \%(232,670)$ of all new cancers among women. Cancers of the lung and bronchus, prostate, and colorectum in men and cancers of the lung and bronchus, breast, and colorectum in women continue to be the most common causes of cancer death. These 4 cancers account for almost half of the total cancer deaths among men and women, with more than onequarter of all cancer deaths due to lung cancer. An urgent need in cancer control today is to develop effective and affordable approaches to the early detection, diagnosis, and treatment of cancer (Siegel et al., 2014).

In this regard, Hesa-A is an Iranian patented natural product with herbal/marine origin which is showed to increase the survival rate of end staged patients with metastasis. There are several in vitro studies that evaluated the cytotoxic effects of this extract on different cancer cells.

In a recent study, Muhammmadnejad et al assessed selective growth inhibitory effects of Hesa-A on breast (MCF-7), prostate (PC-3), colon (HCT-116) and glioblastoma multiforme (U-87MG) neoplastic cell lines. They indicated that Hesa-A at the highest concentration $(100 \mu \mathrm{g} / \mathrm{mL})$ significantly inhibited the growth of HCT-116 cell line (40.13\% growth inhibition) and no satisfactory results obtained by the other tested cell lines(Muhammmadnejad et al., 2014).

Aliabadei et al evaluated the cytotoxicity of HESA-A on MDA-MB-468 (breast cancer ), Hep-2 (human liver carcinoma cell line), Hela as cancer cells (Cervical cancer). L929 and McCoy used as normal cells. Different concentrations of $0.4,0.2,0.1$ and $0.05 \mathrm{mg} / \mathrm{ml}$ of Hesa-A was used in MTT assay. Hesa-A $(0.4 \mathrm{mg} / \mathrm{ml})$ reduced the number of viable MDA-MB-468 and Hela cells to less than 50\%. For Hep-2 cells the IC50 was $0.8 \mathrm{mg} / \mathrm{ml}$. In normal cells IC50 could not be obtained at any given concentrations. The authors suggested that Hesa-A in therapeutic doses and in a concentration dependent manner inhibits the growth of cancer cells more selectively than normal cells (Sadighi-Aliabadi and Ahmadi, 2003).

Roudkenar, et al concluded that cytotoxic effects of Hesa-A on Chinese hamster ovary (CHO) and human embryonic kidney (HEK293T) could be attributed to its potent anti-oxidant and anti radical activity on these cells (Roudkenar et al., 2012).

It is speculated that Hesa-A is more effective against aggressive and end staged cancers as well as end staged breast cancer, metastatic colon cancer and also aggressive forms of oral neoplasms as confirmed by our group. The results of our study confirms that Hesa-A exert potent cytotoxic effects on different human cancer cells including 
breast, ovarian, prostate and lung cancer even at the lower doses $(100 \mu \mathrm{g} / \mathrm{ml})$.The most promising results obtained with lung non small cell cancer cells which is a rapid growth tumor with a high propensity for invasion and metastasis and shows a fatal prognosis(Shindo-Okada et al., 2002). Similar results obtained with MCF-7 hormone responsive breast cancer cell line. It is shown that MCF7 cells form tumors when injected into athymic nude mice. These tumors are able to metastasize to lungs, liver and spleen. MCF-7 cells secrete into the culture media collagenases able to lyse types I and IV collagens(Shafie and Liotta, 1980). In our study, doses $400 \mu \mathrm{g} / \mathrm{ml}$ of Hesa-A caused to more than $85 \%$ growth inhibition of aggressive lung and breast cancer cells. Hesa-A also showed substantial anti-prolifreative effects on PC-3- prostate adenocarcinoma cells. It is well documented that PC-3 cells have high metastatic potential to bone compared to other prostate cell lines such as DU145 cells which have a moderate metastatic potential and to LNCaP cells which have low metastatic potential(Sanchez-Sweatman et al., 1998).

At the other hand,we tested the effects of Hesa-A on ovarian cancer cells which is a less aggressive tumor compared to lung, prostate and breast cancer cells. Our result indicated that $400 \mu \mathrm{g} / \mathrm{ml}$ doses of Hesa-A caused to $79.3 \%$ growth inhibition of ovarian cancer cells. The highest IC50 of $200 \mu \mathrm{g} / \mathrm{ml}$ required to result in $50 \%$ growth inhibition of SKOV3 cells whilst in the other tumor cells doses $\leq 100 \mu \mathrm{g} / \mathrm{ml}$ of Hesa-A suffice to reduce cell viability to less than $50 \%$ and values close and comparable to that of Toxol as positive control.

In conclusion, the results of this study suggest that Hesa-A possess potent cytotoxic effects on the most human common cancers even at the lower doses and yet it is more effective against tumors with high propensity for invasion and metastasis as well as lung non small cancer cells, breast adenocarcinoma and prostate adenocarcinoma, however the mechanism of action need to be addressed.

\section{Acknowledgements}

This study is funded by a grant of Student Research Committee (SRC), Tabriz, Iran.

\section{References}

Abbasi MM, Khiavi MM, Monfaredan A, et al (2014a). DOXMTX-NPs augment p53 mRNA expression in OSCC model in rat: effects of IV and oral routes. Asian Pac J Cancer Prev, 15, 8377-82.

Abbasi MM, Monfaredan A, Hamishehkar H, et al (2014b). New formulated "DOX-MTX-loaded nanoparticles" downregulate HER2 gene expression and improve the clinical outcome in OSCCs model in rat: the effect of IV and oral modalities. Asian Pac J Cancer Prev, 15, 9355-60.

Abbasi MM, Monfaredan A, Hamishehkar H, et al (2014c). Novel DOX-MTX nanoparticles improve oral SCC clinical outcome by down regulation of lymph dissemination factor VEGF-C expression in vivo: oral and IV modalities. Asian Pac J Cancer Prev, 15, 6227-32.

Ahmadi A, Habibi G, Farrokhnia M (2010a). Anticancer effects of HESA-A: an herbal marine compound. Chin J Integr Med, 16, 366-7.

Ahmadi A, Mohagheghi M, Karimi M, et al (2009). Anticancer effects of HESA-A in patients with metastatic colon cancer. Integr. Cancer Ther, $8,71-4$.

Ahmadi A, Mohagheghi MA, Fazeli MS, et al (2005). HESA-A: new treatment for breast cancer and choroidal metastasis. Med Sci Monit, 11, 300-3.

Akbarzadeh A, Zarghami N, Mikaeili H, et al (2012). Synthesis, characterization, and in vitro evaluation of novel polymercoated magnetic nanoparticles for controlled delivery of doxorubicin (Article). Nanotechnol Sci Applic, 5, 13-25.

Elham Abbasi, Sedigheh Fekri Aval, Abolfazl Akbarzadeh, et al (2014). Dendrimers: synthesis, applications, and properties. Nanoscale Res Letters, 9, 247.

Fallahzadeh S, Bahrami H, Akbarzadeh A, Tayarani M (????). High-isolation dual-frequency operation patch antenna using spiral defected microstrip structure. Antennas Wireless Propagation Letters, 9, 122-4

Jahanban Esfahlan R, Zarghami N, Rahmati-Yamchi M, et al (2011). Quantification of steroid receptors gene expression in breast cancer patients: possible correlation with serum level of adipocytokines. J Cancer Therapy, 2, 659-65.

Mehdipour M, Taghavi ZA, Mesgari AM, et al (2013). Evaluation of the effect of two systemic doses of HESA-A on prevention of induced tongue neoplasm in rats. J Dent Res Dent Clin Dent Prospects, 7, 218-24.

Mohammadzadeh G, Zarghami N (2009) Associations between single-nucleotide polymorphisms of the adiponectin gene, serum adiponectin levels and increased risk of type 2 diabetes mellitus in Iranian obese individuals. Scand J Clin Lab Inv, 69, 764-71.

Mohammad Kouhi, Ali Vahedi, Abolfazl Akbarzadeh, Younes Hanifehpour, Sang Woo Joo (2014). Investigation of Quadratic Electro-Optic Effects and Electro Absorption Process in GaN/AlGaN Spherical Quantum Dot. Nanoscale Res Letters, 9, 131-6.

Mollazade M, Nejati-Koshki K, Akbarzadeh A, et al (2013) Dendrimers augment inhibitory effects of curcumin on cancer cell proliferation: Possible inhibition of telomerase. Asian Pac J Cancer Prev, 14, 6925-8.

Muhammmadnejad S, Zendehdel K, Mazaheri Z, et al 2014. Assessment of selective growth inhibitory effects of HESA-A on some human neoplastic cell lines.

Nasiri M, Zarghami N, Nejati Koshki K, et al (2013). Curcumin and silibinin inhibit telomerase expression in T47D human breast cancer cells. Asian Pac J Cancer Prev, 14, 3449-53

Roudkenar MH, Bahmani P, Halabian R, et al (2012). HESA-A exerts its cytoprotective effects through scavenging of free radicals: an in vitro study. Iran JMed Sci, 37, 47-53.

Sadighi-Aliabadi H, Ahmadi A (2003). Cytotoxicity and antitumor properties of a marine compound, Hesa-A, on cancer cells. DARU J Pharmaceutical Sciences, 11.

Shafie SM, Liotta LA (1980). Formation of metastasis by human breast carcinoma cells (MCF-7) in nude mice. Cancer Letters, 11, 81-7.

Siegel R, Ma J, Zou Z, et al (2014). Cancer statistics, 2014. CA: A Cancer Journal for Clinicians, 64, 9-29.

Valiyari S, Jahanban-Esfahlan R, Zare Shahneh F, et al (2013). Cytotoxic and apoptotic activity of Scrophularia oxysepala in MCF-7 human breast cancer cells. Toxicological \& Environmental Chemistry, 95, 1208-20.

Zarghami N, Yu H, Diamandis EP, et al (1995). Sutherland, D.J.A.Quantification of creatine kinase BB isoenzyme in tumor cytosols and serum with an ultrasensitive timeresolved immunofluorometric technique. Clin Biochem, 28, 243-53. 